\title{
Effect of oestrogen as a radioprotective agent on the structural changes of testis in irradiated rats.
}

\author{
Mamdouh, A. Ghali and Fathia, I. Khamis \\ HistologyDepartment Al-Azhar faculty of Medicine and Department of Radiation \\ Biology - National centre for Radiation Research and Technology.
}

\begin{abstract}
The present study aimed to evaluate the histological changes of the testis in an irradiated rat under the effect of oestrogen as a radioprotective agent.

Eighty adult male albino rats were used in this work and divided into 8 equal groups. Group I was considered as a control, group II was exposed to gamma radiation at a dose rate 6 Gy, group III was intramuscularly injected with a single dose of oestrogen $(0.166 \mathrm{mg} / 100 \mathrm{~g}$ b.w.), group IV was injected with fractionated doses of oestrogen $(0.09 \mathrm{mg} / 100 \mathrm{~g} \mathrm{b.w}$.) daily for 7 days, group V \& VI were injected with the same single and fractionated doses $10 \& 5$ days pre-irradiation respectively, group VII \& VIII were injected with the same single and fractionated doses $7 \& 5$ days post-irradiation respectively.

Twenty-one days post-irradiation and treatment, the animals were sacrificed, the testis was isolated and paraffin sections were prepared and stained by haematoxylin and eosin to study the general microscopic structure as well as measurement of thickness of germinal epithelium and diameter of seminiferous tubules. The obtained data were statistically analyzed by Student's ttest.

The irradiated testis showed vacuolization and necrosis of spermatogenic cells, damage of Sertoli cells, rare sperms and reduction of, the germinal epithelium thickness and the diameter of seminiferous tubules in comparison with control group.

With injection of both doses of oestrogen or pre-irradiation injection, the testis was nearly similar to normal pattern. On the other hand, with post-irradiation injection, the testis was nearly similar to irradiation pattern.

It was concluded that pre-irradiation injection of single or fractionated doses of oestrogen could result in improving the effect on the structural changes of testis in the irradiated rat.
\end{abstract}

\section{Introduction}

Testicular tissue represents one of the most radiosensitive body components in animals (Meistrich et al., 1978). Its importance as a subject of study on the cell and tissue levels comes from this activity in cell proliferation and differentiation, as well as its functional importance in reprod-uction. The effect of gamma radiation on the function of gonads revealed complete sterility after using suitable doses of radiation (Ivanova and Maleeva, 1980). Radiation induces damage to Leydig cells which are responsible for the synthesis and secretion of androgen that regulates the development and function of the male reproductive system and promotes spermatogenesis and sperm vitality (Ganong, 1979). Other investigators have reported a decrease in the levels of serum testosterone (Hall and Gones, 1975). Radiation causes reduction of tubule diameter and decrease or loss of germ cells in various developing stages, especially spermatogenic elements (Zhang, at el., 2000). So, it can irreversibly damage spermatogenesis in oncological patients (Kamischke, et al., 2003). The marked 
ability of oestrogen to ameliorate radiation injury was noted in radiotherapy (Mirand et al., 1954). Postmenopausal patients showed much more drastic symptomatic reaction than that of premenopausal cases. It was noted also that endogenous levels of oestrogen are sufficiently high to afford protection against radiation injury in the pre-menopausal state but are lacking in postmenopausal period (Suzuki et al., 1990). The combination treatment of an estrogen with testosterone appears to be effective for stimulating recovery of spermatogenesis in irradiated rats (Shetty, et al., 2004).

The present research was designed to study the protective effect of oestrogen injected in a single and fractionated doses pre and post-irradiation on the histological changes of testis in irradiated rats.

\section{Material And Methods}

Eighty adult male albino rats weighing $(100-120 \mathrm{~g})$ were used in this work. Oestrogen "oestradiol benzoate" Folone, Misr Co. "17-B-oestradiol-3benzoate" in corn oil "0.5 ml corn oil" per animal was injected intramuscularly according to Fakhry et al. (1988).

The animals were classified into 8 equal groups: Group I : Control group injected intramuscularly with $0.5 \mathrm{ml}$ corn oil; Group II exposed to gamma radiation at a dose rate of $6 \mathrm{~Gy}$ and source of activity was 3032 curies; Group III injected with a single dose of oestrogen $(0.166 \mathrm{mg} / 100 \mathrm{~g}$ body wt.); Group IV injected with fractionated doses of oestrogen (0.09 $\mathrm{mg} / 100 \mathrm{~g}$ body wt.) daily for 7 days; Group $\mathrm{V}$ injected with the same single dose of oestrogen 10 days pre-irradiation; Group VI injected daily for 7 days with the same fractionated doses of oestrogen, five days pre-irradiation. Group VII injected with the same single dose of oestrogen seven days post irradiation; Group VIII injected with the same fractionated doses of oestrogen daily for 7 days, 5 days post-irradiation.

Twenty one days post-irradiation and treatment, the animals were sacrificed and the testes were isolated and fixed in
Bouin's fluid in preparation for paraffin sectioning. Paraffin sections were stained by haematoxylin and eosin stain (Drury and Wallington, 1980) to study the general microscopic structure. For quantitative study, 15 sections were obtained from testes for measurement of the thickness of germinal epithelium and diameters of seminiferous tubules in micrometers. The results were analyzed statistically according to Student's t-test.

\section{Results}

(A) Histological changes of testis (Fig.110)

With exposure to radiation, the testis revealed vacuolization and necrosis of spermatogenic cells, damage of Sertoli cells, deformation of interstitial cells and fragmented, reduced, disrupted and incomplete germinal epithelium as well as desquamated cellular debris, rare sperms and decrease of the interstitial tissue and diameter of seminiferous tubules.

After injection of single and fractionated doses, the spermatogenic cells and the interstitial tissue did not show any structural changes.

With pre-irradiation injection of single and fractionated doses, the spermatogenic cells, Sertoli cells, tubules shape and the interstitial tissue were nearly similar to normal pattern with less compact bundles of sperms.

On the other hand, in post-irradiation, and injection of single and fractionated dose, the testis revealed reduced germinal epithelium and interstitial tissue, vacuolization and less deformation of spermatogenic and interstitial cells and central cellular debris with tubules distortion.

(B) Quantitative changes of testis (the table, Fig. $11 \& 12$ )

After exposure to radiation, the mean thickness of germinal epithelium was $(22.55 \pm 0.46)$ while the mean diameters of tubules $(165.11 \pm 2.14)$ were significantly lower than that of the control group (43.63 \pm 0.58 \& $193.56 \pm 3.51)$. 
After injection of single and fractionated doses, The mean thickness of germinal epithelium and the mean diameter of tubules showed no significant changes.

With pre-irradiation, injection of single and fractionated doses, the mean thickness of germinal epithelium was $(42.86 \pm 0.65 \& 42.26 \pm 0.71)$ and the mean diameter of tubules $(189.58 \pm 2.82 \&$ $186.24 \pm 2.95)$ respectively, both revealed no significant difference in relation to control group.

On the other hand, with postirradiation injection of single and fractionated dose, the mean thickness of germinal epithelium was $(22.61 \pm 0.56 \&$ $20.26 \pm 0.5)$ and the mean diameter of tubules $(165.29 \pm 2.46 \& 148.29 \pm 2.2)$ respectively showed significant decrease in relation to control group.

\section{Legand Of Figures}

Fig.-1 Photomicrograph of a section in the control testis showing the normal testicular structure. ( Hx.\&E. stain X 150).

Fig.-2 Photomicrograph of a section in the control testis showing the different normal spermatogenic cells and the interstitial tissue. ( Hx.\&E. stain X 400).

Fig.-3 Photomicrograph of a section in the irradiated testis showing marked affection of the seminiferous tubules in the form of decreased number of spermatogenic cell layers, vacuolization and absence of luminal sperms. ( Hx.\&E. stain X 150).

Fig.-4 Photomicrograph of high power in a section in the irradiated testis showing the same microscopic changes in the previous figure.

( Hx.\&E. stain X 400).

Fig.-5 Photomicrograph of a section in the testis treated only by a single dose of estrogen ,showing no microscopic changes. (Hx.\&E. stain X 400).

Fig.-6 Photomicrograph of a section in the testis treated by fractionated doses of estrogen,showing no microscopic changes. (Hx.\&E. stain X 400).

Fig.-7 Photomicrograph of a section in the irradiated testis treated by a single dose of estrogen before the irradiation, showing normal testicular tissue and normal spermatogenesis . ( Hx.\&E. stain X 400).

Fig.-8 Photomicrograph of a section in the irradiated testis treated by a fractionated doses of estrogen before the irradiation, showing normal testicular tissue and normal spermatogenesis . ( Hx.\&E. stain X 150).

Fig.-9 Photomicrograph of a section in the irradiated testis treated by a single dose of estrogen after the irradiation, showing marked testicular changes in the form of reduced spermatogenic cell layers and absence of luminal sperms as well as central cellular debris.( Hx.\&E. stain X 150).

Fig.-10 Photomicrograph of a section in the irradiated testis treated by a fractionated doses of estrogen after the irradiation, showing marked testicular changes in the form of reduced spermatogenic cell layers and absence of luminal sperms as well as central cellular debris. ( Hx.\&E. stain X 150). 


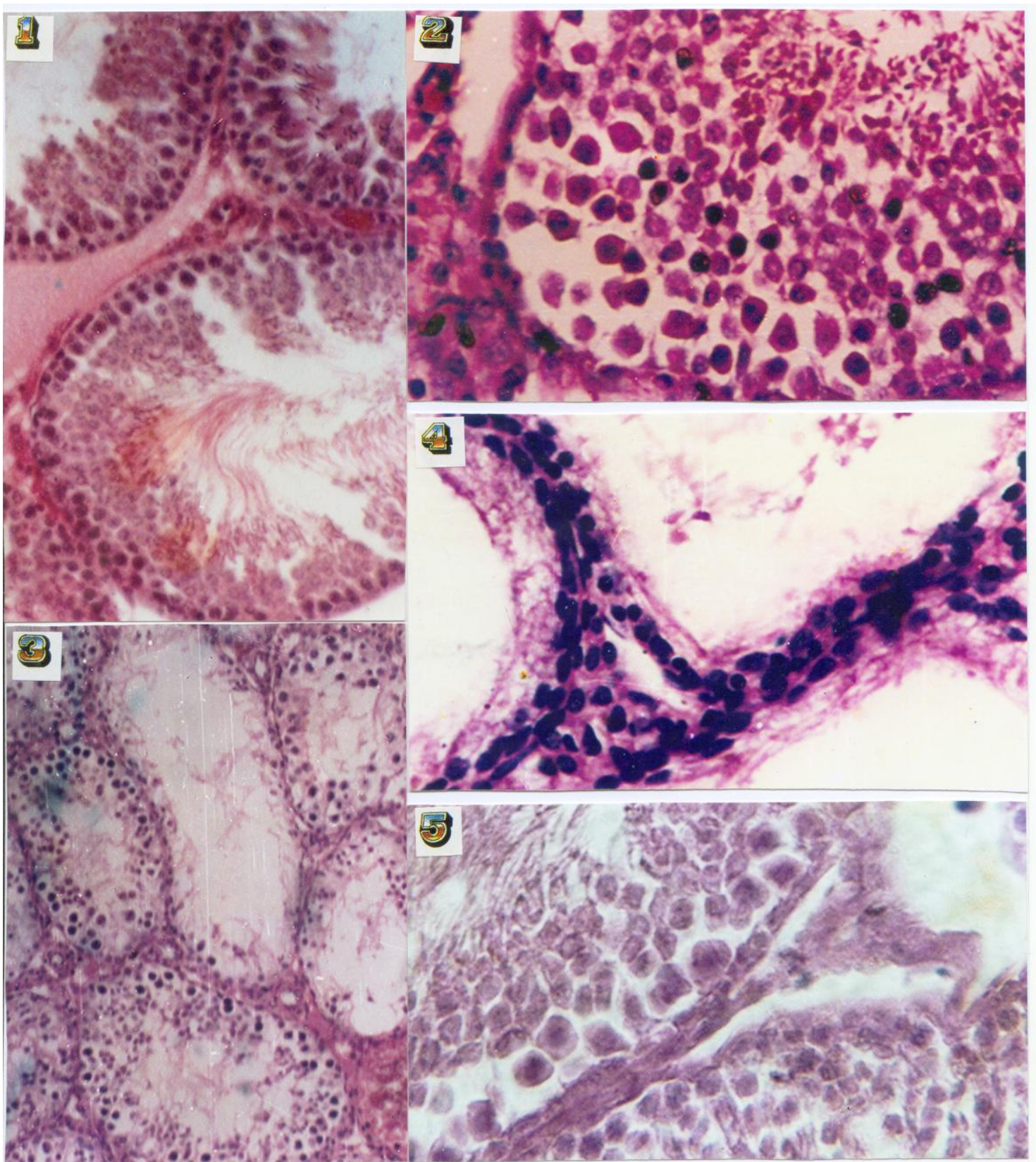


Effect of oestrogen as a radioprotective agent on the.............

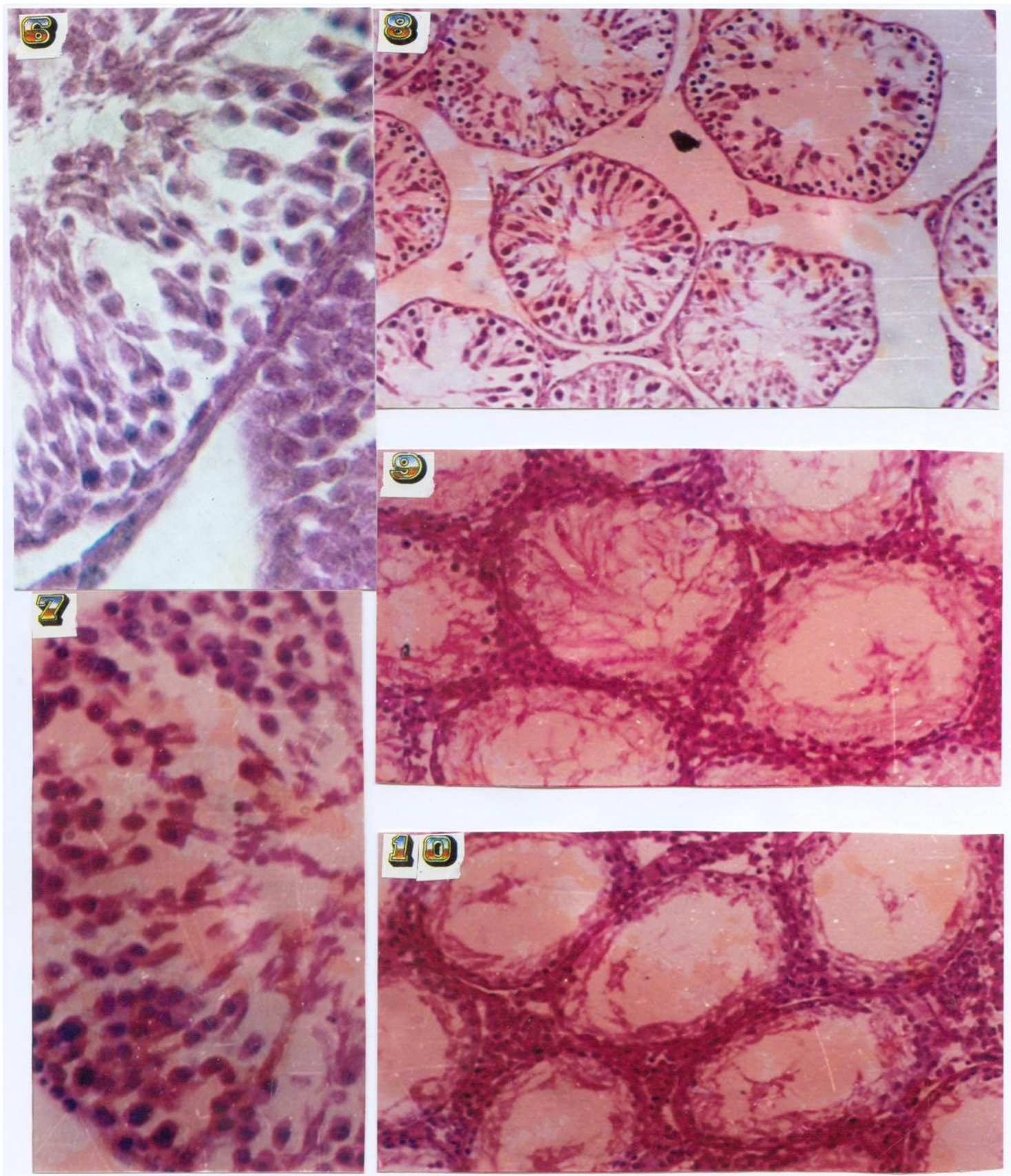


Mamdouh, A. Ghali \& Fathia, I. Khamis

\begin{tabular}{|l|l|l|l|l|l|l|l|l|}
\hline \multirow{2}{*}{} & \multirow{2}{*}{ G.1 } & \multirow{2}{*}{ G. 2 } & \multicolumn{3}{|c|}{ Single dose } & \multicolumn{3}{c|}{ Fractionated doses } \\
\cline { 4 - 9 } & & & G. 3 & G. 5 & G. 7 & G. 4 & G. 6 & G. 8 \\
\hline Mean & 43.63 & 22.55 & 43.41 & 42.86 & 22.61 & 42.59 & 42.26 & 20.26 \\
\hline SD & 2.26 & 1.77 & 2.77 & 2.52 & 2.17 & 3.13 & 2.74 & 1.94 \\
\hline SE & 0.58 & 0.46 & 0.72 & 0.65 & 0.56 & 0.81 & 0.71 & 0.5 \\
\hline T-value & & 28.49 & 0.24 & 0.88 & 25.95 & 1.04 & 1.49 & 30.39 \\
\hline P-value & & $<0.05$ & $>0.05$ & $>0.05$ & $<0.05$ & $>0.05$ & $>0.05$ & $<0.05$ \\
\hline Significance & & ++ & N.S. & N.S. & ++ & N.S. & N.S. & ++ \\
\hline
\end{tabular}

\begin{tabular}{|l|l|l|l|l|l|l|l|l|}
\hline \multirow{2}{*}{} & \multirow{2}{*}{ G.1 } & \multirow{2}{*}{ G. 2 } & \multicolumn{3}{|c|}{ Single dose } & \multicolumn{3}{c|}{ Fractionated doses } \\
\cline { 4 - 9 } & & & G. 3 & G. 5 & G. 7 & G. 4 & G. 6 & G. 8 \\
\hline Mean & 193.56 & 165.11 & 191.32 & 189.58 & 165.29 & 189.59 & 186.24 & 148.29 \\
\hline SD & 13.57 & 8.27 & 11.34 & 10.93 & 9.51 & 12.74 & 11.42 & 8.53 \\
\hline SE & 3.51 & 2.14 & 2.93 & 2.82 & 2.46 & 3.29 & 2.95 & 2.2 \\
\hline T-value & & 6.93 & 0.49 & 0.89 & 6.61 & 0.83 & 1.6 & 10.94 \\
\hline P-value & & $<0.05$ & $>0.05$ & $>0.05$ & $<0.05$ & $>0.05$ & $>0.05$ & $<0.05$ \\
\hline Significance & & ++ & N.S. & N.S. & ++ & N.S. & N.S. & ++ \\
\hline
\end{tabular}


Effect of oestrogen as a radioprotective agent on the............

Fig.11: Changes in the Mean thickness of germinal epithelium of seminiferous tubules in the different groups of the study

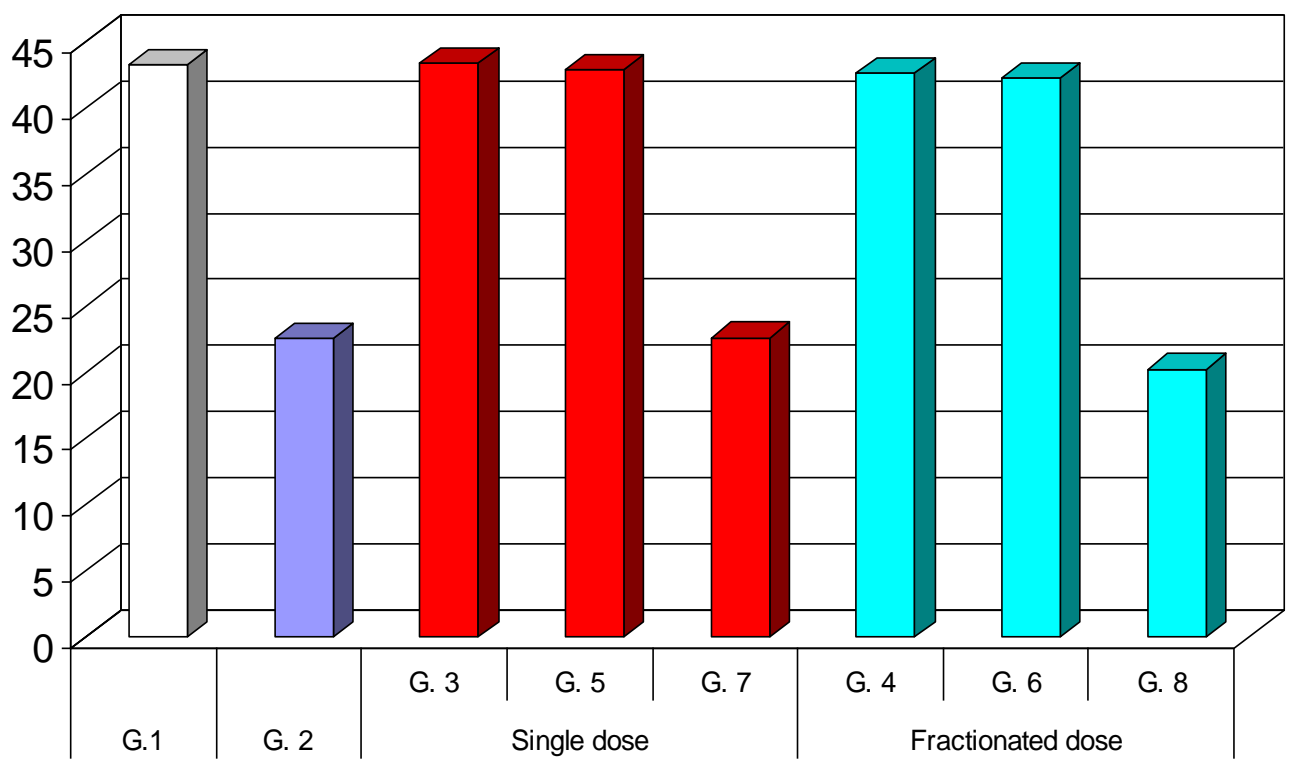

Fig.12: Changes in the mean diameter of seminiferous tubules in the different groups of

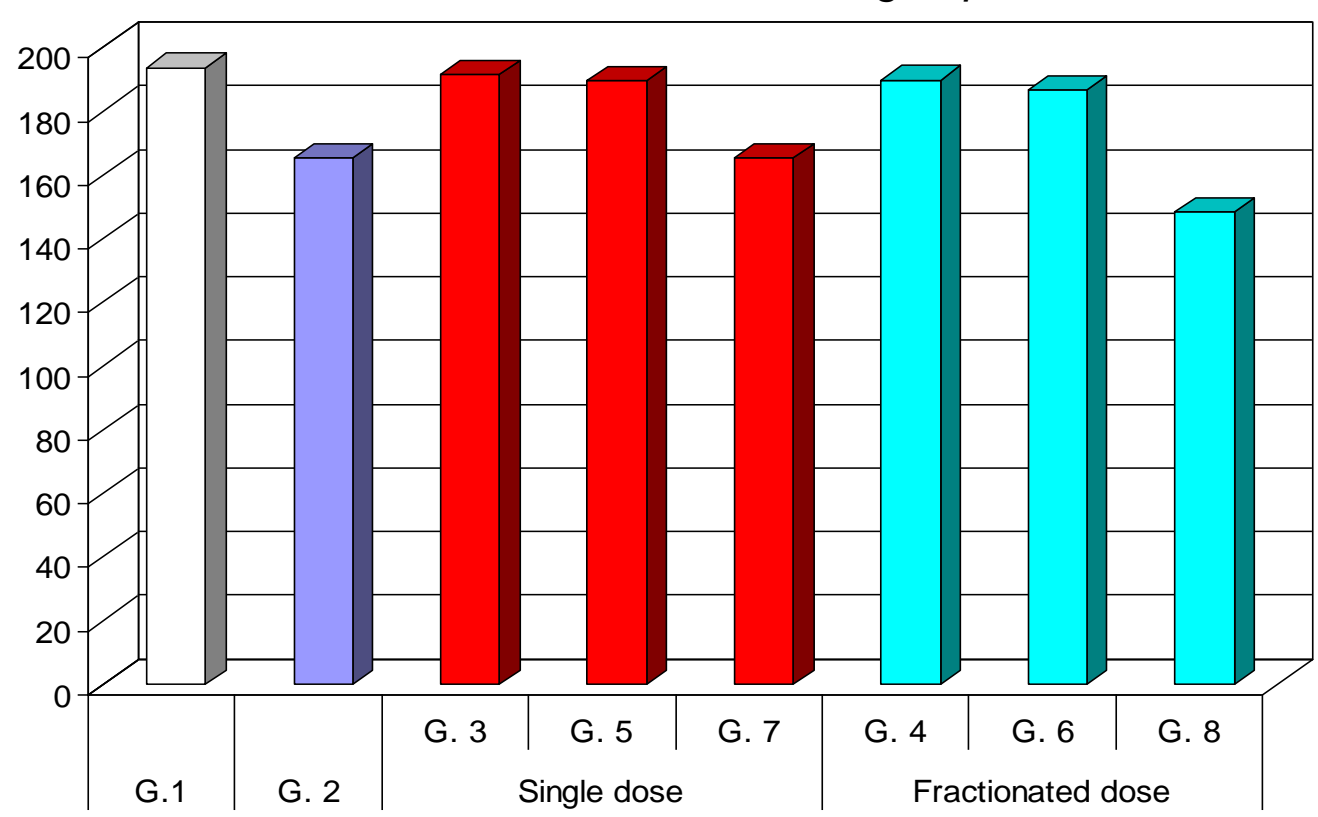

\section{Discussion}


The observed effect of low doses $(6$ Gy) of gamma radiation on the histological changes of testis indicates that such exposure is certainly hazardous to exposed individuals. The present study showed histological changes in irradiated rat testis. The extent of damage, lowering fertility, is posttreatment interval and dose dependent (Bansal et al., 1990). The effect of irradiation was observed on the post-irradiation 21 st day as vacuolization and necrosis of spermatogenic cells, damage of Sertoli cells, rare sperms and reduction of both germinal epithelium and interstitial tissue. These results were in agreement with the studies of Yang et al., (1987), Morris et al. (1988) and zhang et al., (2000). The reduction of germinal epithelium is correlated to androgen-binding protein decline and FSH rise (Pineau et al., 1989). It may be due to a maturation-depletion process caused by killing of spermatogonia (Peltola et al., 1993) or due to spermatogenesis arrest caused by inhibition of cell division (Morris, 1993). The observed necrosis may be due to anabolic enzymes activity decrease (Nehru et al., 1991) and cytoplasmic vacuolization may be due to lipid droplets and lysosomes increase (Bernacchi et al., 1993). The rare sperms may be due to reduction of nucleic acid and protein content in the testes (Varga et al., 1994). The diameters reduction of seminiferous tubules runs parallel with post-irradiation reduction of testicular and epididymal weights (Pinon-Lataillade et al., 1991). The reduction of interstitial tissue is correlated to irradiation effect on steroid hormones production in testes (Inano et al., 1989).

The pre-irradiation injection of oestrogen acts as a radioprotector which is confirmed by normalization of the histological patterns of the testes. This may be due to interleukin-1 bioactivity increase which is a spermatogonial growth factor, stimulating DNA synthesis (Hakovirta et al., 1993), due to prevention of lipid peroxidation process occurrence in testes (Bernacchi et al., 1993), due to the role of oxygen, thiols and repair of DNA damage in the protective effect (Wilson, et al., 1999), due to blocking of gonadotropin secretion (Kamischke, et al., 2003) or enhancement of spermatogenic recovery which results from prevention of an injury-induced change in spermatogonia, an increase in the numbers of surviving stem cells or their ability to differentiate is enhanced (Meistrich et al., 2000). So, the observed damage dose not reach irreversible stages. The result indicates the protective effect of pre-irradiation single and fractionated doses injection of oestrogen which was supported by Patt et al., (1949), Yousri et al., (1991), Tong et al., (1992) and Shetty et al., (2004).

The post-irradiation injection of oestrogen showed marked reduction of the histological patterns of the testis on $21 \mathrm{st}$ day. This detected an adverse irreversible effect in relation to the pre-irradiation injection effect. This result was supported by Bansal et al. (1990).

In conclusion, irradiation leads to an interference with the normal reproductive processes and the pre-irradiation injection of single or fractionated doses of oestrogen could give the best effect in the histological changes of testis in the irradiated rats. So, it will be possible to predict the efficacy of new treatment to preserve fertility in men being treated for cancer.

\section{References}

1-Bansal, M.R.; Kaul, A.; Tewari, M. and Nehru, B. (1990): Spermatogenesis and epididymal sperm after scrotal gamma irradiation in adult rats. Reprod. Toxicol., 4 (4):321.

2-Bernacchi, A.S.; de-Ferreyra, E.C.; deCastro, C.R. and Castro, J.A.. (1993): Ultrastructural alterations in testes from rats treated with cysteine. Biomed. Environ. Sci., 6(2):172.

3-Drury, R.A. and Wallington, E.A. (1980): Histological techniques,5th Ed. Oxford, N. Y.;Toronto,Oxford University Press, P.27.

4-Fakhry, F.M.; El-Anwar, A.H.; Ateia, M.M. and Aboul-Ela, A. (1988): The effects of oestrogen and progesterone on hepatorenal functions, electrolytes and trace elements in ovariectomized rats. Zagazig Vet. J., 2(B): 121.

5-Ganong, W.F.(1979): The male reproductive system, In 'Review of Medical Physiology', 9th edition (Lange Medical Publications, Drawer, Los Anglos, California) p.333.

6-Hakovirta, H.; Penttila, T.L.; Pollanen, P.; Froysa, B.; Soder, O. and Parvinen, M. (1993): Interleukin-1 bioactivity and DNA synthesis in $\mathrm{X}$-irradiated rat testes. Int.J.Androl., 16(2): 159.

7-Hall, R.W., and Gones, W.R. (1975): The effect of artificial cryptochidism on serum 
oestrogen and testosterone levels in the adult male rat. Acta Endocr., 80:583.

8-Inano, H.; Suzuki, K.; Ishii-Ohba., H.; Imada., Y.; kumagai., R.; Kurihara, S. and Sato, A. (1989): Steroid hormone production in testis, ovary and adrenal gland of immature rats irradiated in utero with 60 Co. Radiat. Res., 117(2):293.

9-Ivanova, B., and Maleeva, A., (1980): Effect of different doses of gamma rays on the content of testosterone, follicle stimulating hormone and luteinizing hormone in rat blood plasma. Radiobiologiya, 20(2): 285.

10- Kamischke A, Kuhlmann M, Weinbauer GF, Luetjens M, Yeung CH, Kronholz HL and Nieschlag E. (2003): Gonadal protection from radiation by $\mathrm{GnRH}$ antagonist or recombinant human FSH: a controlled trial in a male nonhuman primate (Macaca fascicularis) J Endocrinol Nov; 179(2):183.

11-Meistrich, M.L.; Munter, N.R.; Suzuki, N.; Trestle, P.K. and Withers, H.R. (1978): Gradual regeneration of mouse testicular stem cells after exposure to ionizing radiation. Radiat. Res., 74:349.

12- Meistrich ML, Wilson G. Kangasniemi M and Huhtaniemi I (2000): Mechansim of protection of rat spermatogenesis by hormonal pretreatment: stimulation of spermatogonial differentiation after irradiation. J Androl. May-Jun;21(3):464.

13-Mirand, E.A.; Hoffman, J.G.; Reinhard, M.C. and Goltz, H.L. (1954): Sex hormones as protective agents against radiation mortality in mice. Endocrinology, 86:24.

14-Morris, I.D. (1993): Protection against cytotoxic-induced testis damage-experimental approaches. Eur. Urol., 23(1): 143.

15-Morris, I.D.; Delec, J.I.; Hendry, J.H. and shalet, S.M. (1988): Lack of protection by oestrogen from radiation-induced testicular damage in rats. Radiother. Oncol.,11(1): 83.

16-Nehru, B.; Tiwari, M.; Kaul, A.and Bansal, M.R. (1991): Changes in phosphatases and lipids following scrotal gamma irradiation in adult rat testis. Indian.J,Exp. Biol., 29(8): 770.

17-Patt, H.M.; Straube, R.L.; Tyeww, E.B.; Swift, M.N. and Smith, D.E. (1949): Influence of oestrogens on the acute Xirradiation syndrome. Am. J. Physiology, 159:269.

18-Peltola, V.; Parvinen, M.; Huhtaniemi, I.; Kulmala, J. and Ahotupa, M. (1993): Comparison of effects of 0.5 and 3.0 Gy xirradiation on lipid peroxidation and antioxidant enzyme function in rat testis and liver. J.Androl., 14(4): 267.
19-Pineau, C.; Velez-de-la-Calle, J.F.; PinonLataillade, G. and Jegou, B. (1989): Assessment of testicular function after acute and chronic irradiation: further evidence for an influence of late spermatids on Sertoli cell function in the adult rat. Endocrinology., 124 (6): 2720.

20-Pinon-Lataillade, G.; Viguier-Martinez, M.C.; Touzalin, A.M.; Maas, J. and Jegou, B. (1991): Effect of an acute exposure of rat testes to gamma rays on germ cells and on Sertoli and Leydig cell functions. Reqrod. Nutr. Dev., 31(6): 617.

21- Shetty G, Weng CC, Bolden-Tiller OU, Huhtaniemi I, Handelsman D.J and Meistrich ML (2004): Effects of medroxyprogesterone and estradiol on the recovery of spermatogenesis in irradiated rats. Endocrinology. Oct; 145 (10):4461.

22-Suzuki, K.; Takahashi, M.; Ishii-Ohba, H.; Ikeda, K. and Inano, H. (1990): Spermatogenesis in the testis and the adrenals of adult male rats after gammairradiation in utero at late pregnancy, J.Steroid Biochem., 35(2): 301.

23-Tong, S.Z.; Gan, G.Z.; Li,L. and Tang, Z.M. (1992): Synthesis and properties of 3,17 disubstituted estrogenic steroids. YaoHsuchpao., 27(3):236.

24-Varga, S.V.; Demchenko, V.N.; Chaikovskaia, L.V. and Reznikov, A.G.(1994): The reproductive function of male rats in the late periods after X-ray irradiation. Radiats-Biol-Radioecol., 34(1): 105.

25- Wilson G, Kangasniemi $M$ and Meistrich ML(1999): Hormone pretreatment enhances recovery of spermatogenesis in rats after neutron irradiation. Radiat Res. Jul; 152(1):51.

26-Yang, P.C.; Tsay, C.Z.; Tsay, M.T. and Lin, H.K. (1987): Pathological changes in whole body gamma-irradiated Spef Lan-Yu miniature pigs. J. Chin. Soc. Vet. Sci., 13(3): 290.

27-Yousri, R.M.; Roushdy, H. and Gawish, M.A.M. (1991): Changes in some blood lipid fractions in whole-body irradiated rats as influenced by some radioisotopes. Isotopenpraxis V., 27(3): 117.

28- Zhang H, Zhang X, Zheng RL, Gao QX, Wei ZQ, Li WJ, Chen WQ, Liang JP, Han GW, Huang T and Xie HM (2000): Alleviation of pre-exposure to low-dose $1608+$ ion on mouse testicular histological damage induced by subsequent high-dose irradiation. Shi Yan Sheng Wu Xue Bao. Jun;33(2):97. 


\section{تأثير الإستروجين كمانع لتأثير الإشعاع على التغيرات الهستولوجية فى الخصية للفئران المشععة}

\section{مدلوح غالمى و فتحية خميس}

قسم الهستولوجيا بكلية طب (بنين) الأزهر - القاهرة

* مركز تكنولوجيا الإشعاع - هيئة الطاقة الذرية

أجرى هذا البحث لدراسة التغيرات الهستولوجية فى الخصية للفأر المشعع تحت تأثنير الإستروجين • وقد استخدم ثمانون من ذكور الفئران البيضـاء البالغة ، قسموا الى ثمانى مجموعات منسـاوية ، عينت

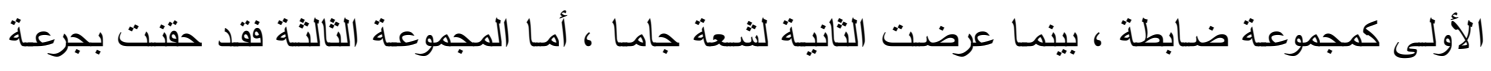
واحدة من الإستروجين بينما حقتت المجموعة الرابعة بجرعات مجزأة ، وقد حقتت أيضـا المجموعة الخامسة والسادسة بنفس الجرعة الواحدة والجرعات المجزأة وذلك قبل التشعيع على الترتيب ، بينما حقتت المجموعة الترات السابعة والثامنـة بنفس الطريقة السابقة ولكن بعد التيشعيع • وقد اسئتصلت الخصبة وتم اعداد قطاعات

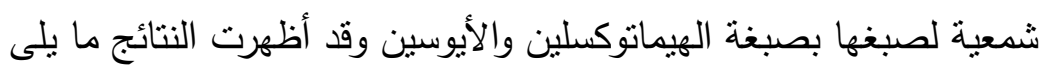
ظهور فراغات وتكسير فى الخلايا المولدة للنطاف ، وأيضاً تكسير فى خلايا سرتولى مع ندرة الحيوانات المنوية بالإضـافة إلى نقص فى كل من النسيج الضـام بين الأنيبيات المنوية وسمك طبقة الخلايا المولدة للنطاف وقطر الأنيبيات المنوية وذلك فى الخصية المشععة بالمقارنة بالمجموعة الضابطة ـ وقد تراجعت كافة الظواهر السابقة فى الخصية وذلك عند الحقن قبل التشعيع ، بينما نظهر نفس الظواهر السابقة فى الخصية وذللك عند الحقن بعد التشعيع بالمقارنة بالمجموعة الضابطة . ويستخلص مما سبق أن حقن الإستروجين بجرعة واحدة أو جرعات مجزأة قبل التشعيع له أكبر الأثر على بلى بلى بلى بله التغيرات الهسنولوجية فى الخصية . 